\title{
Sistem Pendukung Keputusan Pemilihan Crew Store Terbaik Menggunakan Metode Profile Matching di PT Sumber Alfaria Trijaya
}

\author{
Siti Khoiriyah ${ }^{1}$, Yunita ${ }^{2},{ }^{*}$ Agus Junaidi ${ }^{3}$ \\ Address: STMIK Nusa Mandiri, Sistem Informasi, Indonesia ${ }^{1}$, STMIK Nusa Mandiri, Sistem Informasi, Indonesia ${ }^{2}$,
} Universitas Bina Sarana Informatika, Sistem Informasi Akuntansi, Indonesia ${ }^{3}$

Email: skhoiriyah019@gmail.com¹,yunita.yut@nusamandiri.ac.id²,agus.asj@bsi.ac.id²

* Corresponding author

\begin{abstract}
Abstrak
Dalam penentuan sistem pendukung keputusan penilaian kinerja crew store terbaik di PT Sumber Alfaria Trijaya. Terdapat beberapa faktor kriteria dalam pengambilan keputusan kriteria tersebut. Kriteria penilaiannya adalah sikap kerja, komunikasi team work, hasil kerja, dan kedisiplinan. Pada saat ini proses penilaian kinerja cres store PT Sumber Alfaria Trijaya belum terdapat sistem pemilihan crew store dan penilaian masih bersifat subjektif, sehingga proses yang dilakukan masih kurang efektif dan sering mengalami kesulitan dalam pembuatan keputusan. Untuk itu sistem pendukung keputusan sangat membantu dalam hal pengambilan keputusan, dari penilaian kemudian di analisis dengan menggunakan metode profile matching. Dengan metode ini maka PT Sumber Alfaria Trijaya lebih mudah membuat keputusan dalam penilaian kinerja crew store yang sesuai dengan kemampuannya. Penelitian ini adalah untuk mengetahui rangking/bobot nilai dalam penilaian kinerja crew store yang terbaik di PT Sumber Alfaria Trijaya. Dengan adanya penilaian tersebut karyawan bisa dipromosikan sebagai Assistant Chief of store, atau akan diperpanjang masa kerjanya.
\end{abstract}

Keywords - Decision Support System; Profile Matching; The best crew store

\section{Latar Belakang}

Kualitas sumber daya manusia merupakan salah satu faktor penunjang untuk meningkatkan produktivitas kinerja suatu instansi. Adanya sumber daya manusia yang berkualitas merupakan salah satu faktor pendukung yang sangat penting dengan adanya pegawai-pegawai yang berkualitas membuat suatu perusahaan dapat berdiri dengan kokoh, bertumbuh dan berkembang dengan pesat dan menjadi besar. Dengan adanya sumber daya manusia yang berkualitas akan membuat suatu perusahan menjadi meningkat dalam operasionalnya, berkembang secara pesat dan menjadi terkenal [1]. Oleh karena itu diperlukan manajemen sumber daya manusia disuatu perusahaan dengan pemilihan karyawan yang terbaik untuk memacu semangat kerja karyawan dalam meningkatkan operasionalnya, dedikasi dan kinerjnya diperusahaan tersebut sehingga menjadi lebih baik, lebih maju dan berkembang.
Karyawan merupakan salah satu faktor utama dalam kelancaran, kemajuan serta keberhasilan suatu perusahaan. Untuk itu perusahaan harus mampu memotivasi karyawan agar dapat bekerja secara optimal dan selalu memberikan yang terbaik untuk perusahaan [2]

Dalam kehidupan sehari-hari manusia sering dihadapkan pada pilihan untuk mengambil sebuah keputusan. Kemampuan mengambil keputusan yang cepat dan cermat akan menjadi kunci keberhasilan dan persaingan global. Untuk mengambil sebuah keputusan tentu diperlukan analisis-analisis dan perhitungan yang matang, tergantung dengan banyak atau sedikitnya kriteria yang mempengaruhi permasalahan yang membutuhkan suatu keputusan tersebut saling terkait. Sebaiknya perusahaan menerapkan sistem penilaian untuk karyawan agar perusahaan mempunyai karyawan yang berkualitas. Karena pada saat ini kondisi persaingan

Program Studi Teknik Informatika

Universitas Prima Indonesia (UNPRI) Medan 
perusahaan sangatlah tinggi. Untuk mengetahui kualitas karyawan yang baik yaitu adanya sistem penilaian karyawan, penilaian tersebut terdiri dari penilaian kinerja, sikap kerja, team work, hasil kerja dan kedisiplinan.

Dalam penelitian sistem pendukung keputusan ini penulis memilih menggunakan metode profile matching. Karena metode ini pernah dipelajari pada semester sebelumnya. Metode ini diharapkan dapat membatu untuk memberikan hasil keputusan crew store terbaik pada alfamart corodoba 2.

Metode profile matching merupakan salah satu metode yang sederhana dalam sistem pendukung keputusan dengan membandingkan GAP dengan nilai alternatif dan kriteria. Ada beberapa hal yang diketahui tentang analisis GAP, salah satu diantaranya adalah tabel nilai bobot GAP. Selain itu analisis GAP ini juga harus memiliki konsep skala prioritas setiap kriteria [3].

\section{Sistem Pendukung Keputusan}

Sistem pendukung keputusan adalah sistem berbasis computer yang membantu para pengambil keputusan mengatasi berbagai masalah melalui interaksi langsung dengan sejumlah database dan perangkat lunak analitik [4].

Sistem Pendukung Keputusan (SPK) adalah sistem informasi interaktif yang menyediakan informasi, pemodelan dan pemanipulasian data.Sistem itu digunakan untuk membantu pengambilan keputusan dalam situasi yang semistruktur dan situasi yang tidak terstruktur, dimana tidak seorangpun tahu secara pasti bagaimana keputusan harusnya dibuat [5].

\section{Metode}

Dalam memproses pengambilan keputusan tidak bisa ditentukan sekaligus tetapi dilaksanakan melalui beberapa tahapan pengambilan keputusan dilakukan melalui enam tahapan, yaitu :

1. Identifikasi Masalah

2. Pemilihan Metode

3. Pengumpulan data yang dibutuhkan untuk melaksanakan model keputusan

4. Mengimplementasikan model tersebut.

5. Mengevaluasi sisi positif dan sisi alternatif yang ada

6. Melaksanakan solusi terpilih

\section{Metode Pengumpulan Data}

Pada penelitian ini, penulis berusaha untuk mengumpulkan data dan informasi akurat yang dapat menunjang proses dari hasil penelitian. Berikut ini merupakan metode pengumpulan data diperoleh melalui:

\section{Penelitian Lapangan (Field Researching)} Penelitian lapangan adalah penelitian langsung pada objek yang diteliti, dalam hal ini yaitu penelitian kinerja crew store, nilai sikap kerja, komunikas team work, hasil kerja, kedisiplinan, serta kepribadian yang mempengaruhi dalam kriteria penilaian.

2. Observasi, yaitu dengan cara melakukan riset di Alfamart Cordoba 2.

3. Wawancara, dengan melakukan wawancara kepada area manager Alfamart Cordoba2 dengan bapak Didik Prayitno.

4. Kuesioner, yaitu digunakan untuk penilaian crew store Alfamart cordoba 2.

4. Library Researching (Penelitian Perpustakaan)

Penelitian perpustakaan yaitu teknik berdasarkan literatur guna memperoleh dasar teoritis dalam sebuah metode penelitian yang digunakan. Selain itu, pencarian literatur lain berupa jurnal penelitian dengan masalah dan metode serupa sebagai acuan penelitian.

\section{Populasi dan Sampel}

Menurut Kurniawan populasi adalah wilayah generalisasi yang terdiri atas obyek atau subyek yang mempunyai kualitas dan karakteristik tertentu yang ditetapkan oleh peneliti untuk dipelajari dan kemudian ditarik kesimpulan [6].

Populasi dari penelitian ini yaitu crew store Alfamart Cordoba 2 wilayah Jakarta utara dan barat. Menurut Sugiyono "Sampel Merupakan suatu bagian dari populasi. Hal ini mencangkup sejumlah anggota yang dipilih dari populasi. Dengan demikian sebagian elemen dari populasi merupakan sampel" [7].

Pengambilan sampel dalam penelitian ini adalah $30 \mathrm{crew}$ store yang memiliki nilai terbaik dalam hal integritas dan sikap kerja, komunikasi, team work, hasil kerja dan kedisiplinan crew store Alfamart Cordoba 2.

\section{Metode Analisis Data}

Secara umum analasis yang digunakan terdiri dari nilai kedisiplinan, sikap kerja, hasil kerja, dan komunikasi team work crew store Alfamart cordoba 2.

\section{Kedisiplinan}

Penelitian menjadikan kedisiplinan sebagai kriteria penilaian pertama karena kepatuhan atau taat terhadap prosedur aturan yang berlaku.

2. Sikap kerja

Penelitian menjadikan perilaku sebagai kriteria penilaian kedua sikap terhadap tugas yang diberikan.

3. Hasil kerja

Program Studi Teknik Informatika

Universitas Prima Indonesia (UNPRI) Medan 
Penelitian menjadikan kepribadian sebagai kriteria penilaian ketiga terhadap sikap kerja baik dan buruknya crew store.

4. Komunikasi team work

Penelitian menjadikan kehadiran sebagai kriteria penilaian keempat karena dalam pengetahuan dan penguasaan dalam bidangnya.

Metode Gap Kompetensi (Profile Matching)

Berikut adalah tahapan perhitungan rangking pada metode profile matching :

1. Penentuan Bobot Nilai Gap

Setelah didapatkan tiap gap masing-masing karyawan maka tiap profil karyawan diberi bobot nilai dengan patokan tabel bobot nilai gap seperti yang dilihat pada Tabel 1.

Tabel 1. Bobot Nilai Gap

\begin{tabular}{|c|c|c|c|}
\hline No & Selisih & $\begin{array}{c}\text { Bobot } \\
\text { Nilai }\end{array}$ & Keterangan \\
\hline 1 & 0 & 5 & $\begin{array}{l}\text { Kompetensi sesuai dengan } \\
\text { yang dibutuhkan } \\
\text { Kompetensi individu }\end{array}$ \\
\hline 2 & 1 & 4.5 & $\begin{array}{l}\text { kelebihan } 1 \text { tingkat/level } \\
\text { Kompetensi individu }\end{array}$ \\
\hline 3 & -1 & 4 & $\begin{array}{l}\text { kekurangan } 2 \text { tingkat/level } \\
\text { Kompetensi individu }\end{array}$ \\
\hline 4 & 2 & 3.5 & $\begin{array}{l}\text { kelebihan } 2 \text { tingkat/level } \\
\text { Kompetensi individu }\end{array}$ \\
\hline 5 & -2 & 3 & $\begin{array}{l}\text { kekurangan } 2 \text { tingkat/level } \\
\text { Kompetensi individu }\end{array}$ \\
\hline 6 & 3 & 2.5 & $\begin{array}{l}\text { kelebihan } 3 \text { tingkat/level } \\
\text { Kompetensi individu }\end{array}$ \\
\hline 7 & -3 & 2 & $\begin{array}{l}\text { kekurangan } 3 \text { tingkat/level } \\
\text { Kompetensi individu }\end{array}$ \\
\hline 8 & 4 & 1.5 & kelebihan 4 tingkat/level \\
\hline 9 & -4 & 1 & $\begin{array}{l}\text { Kompetensi individu } \\
\text { kekurangan } 4 \text { tingkat/level }\end{array}$ \\
\hline
\end{tabular}

2. Perhitungan dan pengelompokan core faktor dan secondary factor

Setelah menentukan bobot nilai gap untuk ketiga aspek kompetensi yang dibutuhkan, kemudian tiap aspek dikelompokan lagi menjadi 2 kelompok, yaitu core faktor dan secondary factor.

Core factor merupakan kompetensi yang sangat dibutuhkan oleh suatu jabatan yang diperkirakan dapat menghasilkan kinerja optimal. Untuk menghitung core factor digunakan rumus 1 :

$$
\mathrm{NCl}=\sum \mathrm{NC} / \sum \mathrm{IC}
$$

Keterangan :

$\mathrm{NCl}$ : Nilai rata-rata core factor kompetensi

NC : Jumlah nilai core factor

IC : Jumlah item core factor

Secondary factor (faktor pendukung) adalah itemitem selain aspek yang ada pada core factor digunakan rumus 2 :

$$
N S I=\sum N S / \sum I S
$$

\section{Keterangan :}

NSI : Nilai rata-rata secondary factor kompetensi

NS : Jumlah total nilai secondary factor kompetensi

IS : Jumlah item secondary factor

3. Perhitungan nilai total tiap kompetensi kriteria

Dari perhitungan core factor dan secondary factor dari tiap-tiap kompetensi dihitung nilai total tiap-tiap aspek yang diperkirakan berpengaruh pada kinerja tiap-tiap profile. Untuk menghitung nilai total dari masingmasing kompetensi digunakan rumus 3 :

$N=60 \% N C+40 \% N S$

Keterangan :

$\mathrm{N}$ : Nilai total tiap aspek kriteria

NC : Nilai core factor

NS : Nilai secondary factor

4. Perhitungan rangking

Hasil akhir dari proses profile matching adalah rangking kandidat yang diajukan untuk mengisi suatu jabatan/posisi tertentu. Penentuan rangking mengacu pada hasil perhitungan yang ditunjukan pada rumus 4 :

Rangking $=(x) \% N K+(x) \% N K$

Keterangan :

$(\mathrm{x}) \%$ : Nilai persen yang dimasukan

NK : Nilai total Kompetensi tiap aspek

\section{Hasil}

Dalam menentukan crew store terbaik alfamart cordoba2 kriteria yang digunakan yaitu:

Tabel 2. Kriteria menentukan crew terbaik

\begin{tabular}{|l|l|}
\hline Kriteria & Aspek Penilaian \\
\hline Kedisiplinan & $\begin{array}{l}\text { a. Kehadiran } \\
\text { b. Loyalitas }\end{array}$
\end{tabular}




\begin{tabular}{|c|c|}
\hline \multirow{5}{*}{ Sikap Kerja } & c. Disiplin Kerja \\
\hline & d. Absensi \\
\hline & a. Perilaku \\
\hline & b. Tanggung Jawab \\
\hline & c. Inisiatif dan Kreatifitas \\
\hline & d. Keuletan dan ketuntasan bekerja \\
\hline & b. Komunikasi \\
\hline $\begin{array}{l}\text { Komunikasi } \\
\text { team work }\end{array}$ & c. Penanganan masalah \\
\hline & $\begin{array}{l}\text { d. Menciptakan lingkungan kerja } \\
\text { yang kondusif }\end{array}$ \\
\hline & a. Penguasaan kerja \\
\hline Hasil Kerja & $\begin{array}{l}\text { b. Kualitas dan kuantitas kerja } \\
\text { c. Kesadaran atas biaya }\end{array}$ \\
\hline
\end{tabular}

Setelah menentukan kriteria dan aspek penilaian maka selanjutnya menentukan Analisis Bobot Nilai Gap. Pemetaan gap yang dimaksud pada pembahasan ini adalah perbedaan kriteria yang dimiliki seorang karyawan dengan kriteria yang ada didalam kinerja karyawan dengan aspek penilaian.

$$
\text { Gap = profile Karyawan - Profile Kinerja }
$$

Dari pembobotan nilai gap aspek integritas dan sikap kerja, maka diperoleh nilai seperti pada tabel 2

Tabel 3. Nilai Gap aspek integritas dan sikap kerja

\begin{tabular}{|c|c|c|c|c|c|}
\hline No & Crew Store & $\underline{\text { SK01 }}$ & $\underline{\mathrm{SKO2}}$ & $\underline{\mathrm{SKO3}}$ & $\underline{\text { SKO4 }}$ \\
\hline 1 & Nurokhmah & -1 & -2 & -2 & -1 \\
\hline 2 & Nurjannah & -1 & 0 & -2 & 0 \\
\hline 3 & Tia & 0 & -1 & -2 & -1 \\
\hline 4 & Syifa & -2 & -1 & -2 & -2 \\
\hline 5 & Aldi & -2 & -2 & -2 & -2 \\
\hline 6 & Iwan & -2 & -1 & -2 & -1 \\
\hline 7 & Agan & -2 & -2 & -2 & -2 \\
\hline 8 & Eko & -1 & -1 & -2 & -1 \\
\hline 9 & Nurul & -1 & 0 & -1 & -1 \\
\hline 10 & Arif & -1 & -1 & -1 & 0 \\
\hline- & --- & --- & --- & --- & --- \\
\hline 29 & Andri & 0 & -1 & -1 & 0 \\
\hline 30 & Firda & -1 & -2 & -1 & -2 \\
\hline
\end{tabular}

Setelah mendapatkan nilai Gap, maka dilakukan pembobotan dengan acuan seperti pada tabel 1 , sehingga menghasilkan nilai pembobotan sebagai berikut:

Tabel 4. Pembobotan nilai Gap aspek integritas dan sikap kerja

No Crew Store SK01 SK02 SK03 SK04

\begin{tabular}{llcccc}
\hline 1 & Nurokhmah & 4 & 3 & 3 & 4 \\
2 & Nurjannah & 4 & 5 & 3 & 5 \\
3 & Tia & 5 & 4 & 3 & 4 \\
4 & Syifa & 3 & 4 & 3 & 3 \\
5 & Aldi & 3 & 3 & 3 & 3 \\
6 & Iwan & 3 & 4 & 3 & 4 \\
7 & Agan & 3 & 3 & 3 & 3 \\
8 & Eko & 4 & 4 & 3 & 4 \\
9 & Nurul & 4 & 5 & 4 & 4 \\
10 & Arif & 4 & 4 & 4 & 5 \\
- & --- & --- & --- & --- & --- \\
29 & Andri & 5 & 4 & 4 & 5 \\
30 & Firda & 4 & 3 & 4 & 3 \\
\hline
\end{tabular}

Selanjutnya dilakukan perhitungan core factor dan secondary factor. Hasil perhitungan core factor dan secondary factor ditampilkan dalam tabel 5.

Tabel 5. Perhitungan core factor dan secondary factor untuk aspek sikap kerja

\begin{tabular}{llcc}
\hline No & Crew Store & $\begin{array}{c}\text { Nilai core } \\
\text { factor } \\
\text { (NCF) }\end{array}$ & $\begin{array}{c}\text { Nilai } \\
\text { secondary } \\
\text { factor (SCF) }\end{array}$ \\
\cline { 3 - 3 } 1 & Nurokhmah & 3,5 & 3,5 \\
2 & Nurjannah & 4,5 & 4 \\
3 & Tia & 4,5 & 3,5 \\
4 & Syifa & 3,5 & 3 \\
5 & Aldi & 3 & 3 \\
6 & Iwan & 3,5 & 3,5 \\
7 & Agan & 3 & 3 \\
8 & Eko & 4 & 3,5 \\
9 & Nurul & 4,5 & 4 \\
10 & Arif & 4 & 4,5 \\
- & --- & --- & --- \\
29 & Andri & 4,5 & 4,5 \\
30 & Firda & 3,5 & 3,5 \\
\hline
\end{tabular}

Dari perhitungan NCF dan NSF, selanjutnya dihitung nilai total tiap kompetensi, sebagai contoh untuk aspek integritas dan sikap kerja diperoleh hasil pada tabel 6 .

Tabel 6. Nilai total untuk aspek sikap kerja

\begin{tabular}{|c|c|c|}
\hline No & Crew Store & Nilai total \\
\hline 1 & Nurokhmah & 3,5 \\
\hline 2 & Nurjannah & 4,3 \\
\hline 3 & Tia & 4,1 \\
\hline 4 & Syifa & 3,3 \\
\hline 5 & Aldi & 3 \\
\hline 6 & Iwan & $\underline{3,5}$ \\
\hline
\end{tabular}




\begin{tabular}{llc}
\hline 7 & Agan & 3 \\
8 & Eko & 3,8 \\
9 & Nurul & 4,6 \\
10 & Arif & 4,2 \\
- & --- & --- \\
29 & Andri & 4,5 \\
30 & Firda & 3,5 \\
\hline
\end{tabular}

Hasil akhir prosese Profile Matching adalah rangking dari Crew store yang akan menjadi Crew store berprestasi.

Penentuan rangking mengacu pada hasil perhitungan tertentu.

Rangking $=(x) \% . S k+(x) \% . K t w+(x) \% . H k+(x) \% . K d$

Keterangan :

Sk : Sikap Kerja

Ktw : Komunikasi Team Work

Hk : Hasil Kerja

Kd : Kedisiplinan

(x) \% : Nilai Persen yang dimasukan

Proses perhitungan rangking setiap kandidat adalah sebagai berikut :

Nilai persentase untuk setiap aspek adalah 10\% (Sikap Kerja), 30\% (Komunikasi Team Work), 20\% (Hasil Kerja), 40\% (Kedisiplinan).

1. Nurokhmah $=(10 \% \times 3.5+30 \% \times 4.5+20 \% \times 2.7+$ $40 \% \times 4.3)=0.35+1.35+0.54+1.72=$ 3.96

2. Nurjannah $=(10 \% \times 4.3+30 \% \times 4.3+20 \% \times 3.7+$ $40 \% \times 3.8)=0.43+1.29+0.37+1.52=$ 3.61

3. Tia $=(10 \% \times 4.1+30 \% \times 3.2+20 \% \times 2.3+$ $40 \% \times 4.0)=0.41+0.96+0.46+1.6=$ 3.43

4. Syifa $\quad=(10 \% \times 3.3+30 \% \times 3.6+20 \% \times 2.7+$ $40 \% \times 3.4)=0.33+1.08+0.54+1.36=$ 3.31

5. Aldi $\quad=(10 \% \times 3.0+30 \% \times 3.4+20 \% \times 2.4+$ $40 \% \times 4.2)=0.30+1.02+0.48+1.68=$ 3.48

6. Iwan

$=(10 \% \times 3.5+30 \% \times 3.2+20 \% \times 2.9+$ $40 \% \times 2.8)=0.35+0.96+0.58+1.12=$ 3.01

7. Agan
8. Eko

9. Nurul

10. Arif

29. Andri

30. Firda
$=(10 \% \times 3.8+30 \% \times 4.4+20 \% \times 4.1+$ $40 \% \times 4.6)=0.38+1.32+0.82+1.84=$ 4.36

$=(10 \% \times 4.6+30 \% \times 4.0+20 \% \times 4.0+$ $40 \% \times 2.6)=0.46+1.20+0.80+1.04=$ 3.50

$=(10 \% \times 4.2+30 \% \times 3.2+20 \% \times 3.3+$ $40 \% \times 3.2)=0.42+0.96+0.66+1.28=$ 3.32

$=(10 \% \times 4.5+30 \% \times 3.2+20 \% \times 3.7+$ $40 \% \times 4.2)=0.45+0.96+0.74+1.68=$ 3.83

$=(10 \% \times 3.5+30 \% \times 4.1+20 \% \times 3.4+$ $40 \% \times 3.1)=0.35+1.23+0.68+1.24=$ 3.50

Tabel 7. Tabel Penentuan Rangking

\begin{tabular}{|c|c|c|}
\hline No & Crew Store & Hasil Akhir \\
\hline 1 & Nurokhmah & 3.96 \\
\hline 2 & Nurjannah & 3.61 \\
\hline 3 & Tia & 3.43 \\
\hline 4 & Syifa & 3.31 \\
\hline 5 & Aldi & 3.48 \\
\hline 6 & Iwan & 3.01 \\
\hline 7 & Agan & 3.82 \\
\hline 8 & Eko & 4.36 \\
\hline $\mathrm{NgO}_{9}$ & Cnewestore & Hasil 50 khir \\
\hline${ }_{1}^{1}{ }_{0}$ & $\mathrm{~A}_{\mathrm{r}} \mathrm{E}_{\mathrm{if}} \mathrm{O}$ & $3^{4} \cdot 3^{3} 26$ \\
\hline 2 & _R_-iri & 4.22 \\
\hline $2^{39}$ & AFnni & $3^{4} \cdot 8^{2} 3^{0}$ \\
\hline $3^{4} 0$ & Spripleld din & $3^{4} \cdot 5^{0} 0^{6}$ \\
\hline 5 & Toharoh & 3.99 \\
\hline 6 & Nurokhmah & 3.96 \\
\hline 7 & Anisya & 3.91 \\
\hline 8 & Andri & 3.83 \\
\hline 9 & Agan & 3.82 \\
\hline 10 & Candra & 3.82 \\
\hline- & --- & --- \\
\hline 28 & Nendi & 3.25 \\
\hline 29 & Iwan & 3.01 \\
\hline 30 & Handoko & 3.01 \\
\hline
\end{tabular}


Tabel 8 Tabel Penentuan Rangking Berdasarkan Hasil Akhir Terbesar

Hasil pengolahan data setiap kandidat mendapat nilai akhir seperti terlihat pada tabel 8, maka bisa ditentukan peringkat atau rangking dari masing-masing kandidat. Berdasarkan pada nilai akhir tertinggi sehingga semakin tinggi nilai hasil akhir maka semakin besar juga kesempatan untuk mendapat predikat Crew Store terbaik. Dari tabel 8 menunjukan bahwa Crew Store dengan nama Eko mendapatkan hasil akhir tertinggi dengan nilai 4.36.

\section{Kesimpulan}

Berdasarkan penelitian yang telah dilakukan untuk proses pemilihan Crew Store terbaik pada PT. Sumber Alfariya Trijaya yang memfokuskan di toko Alfamart Cordoba 2, maka peneliti dapat menarik kesimpulan sebagai berikut :

1. Dengan adanya sistem pengambilan keputusan maka proses pemilihan Crew Store terbaik di PT. Sumber Alfariya Trijaya toko Alfamart Cordoba 2 menjadi lebih cepat dan akurat yang disertakan dengan penilaian kriteria yang telah diterapkan pada metode Profile Matching.

2. Dengan penetapan kriteria-kriteria dan dilakukan perhitungan atau pengolahan data menggunakan metode Profile Matching maka hasil yang diputuskan lebih objektif.

\section{References}

[1] I. G. B. Subawa, I. M. A. Wirawan, and I. M. G.
Sunarya, "Pemilihan Pegawai Terbaik Menggunakan Metode Simple Additive Weighting ( SAW ) di PT Tirta Jaya Abadi Singaraja," Karmapati, vol. 4, no. 5, 2015.

[2] R. I. Handayani, "Sistem Pendukung Keputusan Pemilihan Karyawan Berprestasi Dengan Metode Profile Matching Pada PT. Sarana Inti Persada (SIP)," Pilar Nusa Mandiri, vol. 13, no. 1, pp. 28-34, 2017.

[3] N. Nurjannah, Z. Arifin, and D. M. Khairina, "Sistem Pendukung Keputusan Pembelian Sepeda Motor Dengan Metode Weighted Product," J. Inform. Mulawarman, vol. 10, no. 2, pp. 20-24, 2015.

[4] A. A. Sembiring, A. S. Sembiring, and S. R. Siregar, "Sistem Pendukung Keputusan Penentuan Prioritas Pengembangan Industri Kecil Menengah di Kabupaten Karo Mengunakan Metode Topsis," Maj. IIm. INTI, vol. 13, no. 2, pp. 199-204, 2018.

[5] M. S. Rais, "Sistem Pendukung Keputusan Untuk Pemilihan Lokasi Perumahan Menggunakan Analytical Hierarchy Process (AHP)," Riau J. Comput. Sci., vol. 2, no. 2, pp. 59-72, 2016.

[6] Sudaryono, Metodologi Penelitian, 1st ed. depok, 2017.

[7] E. Iswandy, "Sistem Penunjang Keputusan Untuk Menentukan Penerimaan Dana Santunan Sosial Anak Nagari dan Penyalurannya Bagi Mahasiswa Dan Pelajar Kurang Mampu di Kenagarian BarungBarung Balantai Timur," J. Teknoif, vol. 3, no. 2, pp. 70-79, 2015. 